\title{
Determination of Temporal Changes in the Sinuosity and Braiding Characteristics of the Kizilirmak River, Turkey
}

\author{
Derya Ozturk*, Faik Ahmet Sesli \\ Department of Geomatics Engineering, Ondokuz Mayis University, 55139 Samsun, Turkey
}

Received: June 2, 2015

Accepted: July 6, 2015

\begin{abstract}
In this study, the pattern of the approximately 1,300-km-long Kizilirmak River was recreated in a geographic information system (GIS) environment using data obtained from Landsat TM/ETM+/OLI satellite images from 1987, 2000, and 2013. The temporal changes in the sinuosity and braiding characteristics of the river were determined for the periods 1987-2000 and 2000-13. The right and left shorelines of the Kizilirmak River and the shorelines of islands and bars within the river channel were extracted automatically from the satellite images by integrating the normalized difference water index (NDWI) and modified normalized difference water index (MNDWI). The data required for measuring the sinuosity and braiding characteristics were obtained by evaluating the shorelines in the GIS environment. The braiding index $(B I)$, braid-channel ratio $(B)$, and braiding ratio $(B R)$ were used to determine the braiding of the river, and the sinuosity index was used to determine the sinuosity of the river. The Kizilirmak River was divided into 21 analyzed sections based on the locations of dams. The sinuosity decreased in 15 sections in 1987-2000 and 2000-13. The $B I$, $B$, and $B R$ values decreased in 11 sections in 1987-2000 and in 9 sections in 2000-13. Sinuosity and braiding both decreased in most of the sections downstream of dams; these sections were often subject to uncontrolled sand and gravel extractions.
\end{abstract}

Keywords: river, sinuosity, braiding, Landsat, GIS

\section{Introduction}

The complex structure of rivers and increasing interest in quantitatively representing this complex structure have motivated the study of river patterns, which has become an important subject in river science [1]. The pattern of a riverbed is an important indicator of the river's energy and environmental conditions and the local climate and tectonism. It is important to determine changes in riverbeds when conducting fluvial geomorphological and paleogeographical studies and flood prevention studies that consider river management and riverbed control for settlement and agri-

*e-mail: dozturk@omu.edu.tr culture and recreation activities [2-4]. In this context, it is important to monitor shore zones and morphological changes in rivers for environmental protection, planning, and sustainable development $[5,6]$.

The pattern of a river is an indicator of the physiographic characteristics of an area and can differ depending on geological development, riverbed slope, sediment load, and time [7-12]. Although numerous classification schemes have been presented in the literature, rivers are generally classified as straight, sinuous, or multi-channel (branched) $[7,13]$. Sinuous rivers are classified as regular or irregular, and a river can exhibit both sinuous and multi-channel characteristics [7, 14]. Some rivers have more than one channel, which occurs when channels separate and rejoin again. 
This type of channel is thought to occur in areas of rivers that have variable flow conditions or excessive sediment load, and/or when the river passes through erodible formations [15]. Multi-channel rivers are classified as two types: braided and anastomosing. Braided rivers feature sand and gravel bars within the channel, and anastomosing river channels are separated by islands [11]. However, when rivers are evaluated topologically, both forms may be referred to as braided structures [16].

Rivers generally exhibit sinuous characteristics when the bed slope, flow rate, and erosion are low and exhibit braided characteristics when the bed slope and flow rate increase [8, 17]. Anastomosing rivers are generally observed where banks are stable with plant cover, which prevents lateral migration [11]. However, the banks of braided rivers have eroded characteristics [8].

Sinuosity and braiding were defined in the literature to analyze river patterns, which are also referred to as river planforms $[1,18]$. The sinuosity and braiding of a river result from hydraulic factors and the topography of the drainage basin. Therefore, any changes in the topographic, hydraulic, and hydrological conditions would alter the sinuosity and braiding of the river channel [19-21].

The data required for determining the river planform and for calculating the sinuosity and braiding values can be obtained using ground surveys, Global Navigation Satellite System (GNSS) measurements, maps, aerial photogrammetry, and remote sensing methods [1, 18, 2224]. However, remote sensing is generally an optimal method because it can be used to view the same area on different dates and to obtain measurements in different sections of the electromagnetic spectrum and is fast and economical $[5,25,26]$. Although remote sensing is commonly used to determine shorelines and analyze shoreline changes [27-31], the use of remote sensing for analyzing the river planform and its changes is limited in the literature [32, 33].

In this study, the entire Kizilirmak River was studied. The Kizilirmak River is approximately $1,300 \mathrm{~km}$ long and is located in Turkey. The changes in the planform characteristics of the river were analyzed. The Kizilirmak River exhibited rapid planform changes [3, 34] due to changes in natural conditions and human activities, including the construction of 11 dams, sand and gravel acquisition from the riverbed, and river improvement studies [35-41]. These changes have also introduced important changes in the river's ecological balance, residential and agricultural areas in the riverside, estuary, and Kizilirmak Delta coast [35, 41]. However, few studies have been published regarding the planform characteristics and the changes in the planform characteristics of the Kizilirmak River. In the few studies that have been performed, only a small section of the Kizilirmak River was examined [3, 42, 43]. In this study, the changes in the sinuosity and braiding characteristics of the Kizilirmak River over 26 years (between 1987 and 2013) were determined using image-processing techniques and GIS analyses based on Landsat TM/ETM+/OLI satellite images from 1987, 2000, and 2013, and the causes and effects of the changes are discussed.

\section{Study Area}

The Kizilirmak River (Fig. 1) is the longest river that originates and ends in Turkey [44, 45]. The river is named after the red sandy and clayey sediment that is found in the riverbed. The river developed during the Tertiary period $[46,47]$ and is approximately $1,300 \mathrm{~km}$ long [44].

The river originates at the southern slopes of Kizildag, which is located in Sivas. The river flows west and southwest before flowing in an arc-shape. The river flows west and passes through Lake Tuz in the southwest before turning toward the north and northeast. In this section, Delice Stream, which is one of the largest tributaries, connects to the Kizilirmak River, which continues to flow toward the northwest. After this section, Devrez Stream connects with the Kizilirmak River. The Kizilirmak River flows into the Black Sea at Bafra Cape [46, 47]. Along the river's course, the river passes through Sivas, Kayseri, Nevsehir, Kirsehir, Kirikkale, Ankara, Cankiri, Corum, and Samsun, and gains water from various streams [44]. The route of the river is determined by active fault zones that largely formed during the neotectonic period [48]. The river, which is fed by rain and snow water, has an irregular regime [44]. In addition, the water level of the river is low between July and February, surges rapidly in March, and reaches its peak in April. The average flow rate of the river was $184 \mathrm{~m}^{3} / \mathrm{s}$ between 1972 and 2007. During this period, the lowest flow rate was $18.4 \mathrm{~m}^{3} / \mathrm{s}$, and the highest flow rate was $1,673 \mathrm{~m}^{3} / \mathrm{s}$. The Kizilirmak is diminished during the summer and reaches its lowest level in August [47]. Kizilirmak is also referred to as "Halys," which means 'salty river' in antiquity. The water of the Kizilirmak River, which generally flows from gypsum-bearing land, is salty and brackish [45]. Over thousands of years, the sediments carried by the Kizilirmak River have formed the Kizilirmak Delta [35, 49], which is internationally important and protected by the Ramsar contract $[40,50,51]$. The drainage area of the Kizilirmak River is $78,180 \mathrm{~km}^{2}$ [52], with 11 dams on the primary stem of the river (Fig. 1) [53].

\section{Data and Methods}

To determine the temporal changes in the sinuosity and braiding characteristics of the Kizilirmak River, Landsat satellite images from 1987, 2000, and 2013 were used, and the changes in the characteristics from 1987 to 2000 and from 2000 to 2013 were determined. To determine the braiding of the river, we used the:

i) braiding index $(B I)[23]$,

ii) braid-channel ratio $(B)[18]$,

iii) braiding ratio $(B R)[3]$.

To determine the sinuosity of the river, the sinuosity index [18] was used. The methodology used in this study is presented in Fig. 2. To determine the sinuosity and braiding of the Kizilirmak River, the right and left bank shorelines of the Kizilirmak River and the shorelines of the bars and islands within the river channel were extracted. Then the shorelines were evaluated using GIS, and the sinuosity and 
braiding parameters were calculated. Finally, any changes in these parameters were analyzed. To process the satellite images, the software ENVI 5.1 (Exelis, Herndon, VA) was used. In addition, to extract the shorelines, determine the morphological indexes, and conduct a change analysis, ArcGIS 10.0 software (Esri, Redlands, CA) was used. The data used in this study are explained in the "Data" section, the preprocesses applied to the satellite images are explained in "Image Preprocessing," the extraction of shorelines from the satellite images are presented in "Determination of Shorelines," and the determination of sinuosity and braiding is explained in detail in "Determination of the Sinuosity and Braiding Characteristics of the Kizilirmak River."

\section{Data}

To determine the sinuosity and braiding characteristic changes in the Kizilirmak River, Landsat-5 TM images from 1987, Landsat-7 ETM+ from 2000, and Landsat-8 OLI images from 2013 [54] were used. Overall, 27 images were used (nine images for each analysis year: Path/Row: $174 / 32$, 174/33, 175/32, 175/33, 176/31, 176/32, 176/33, $177 / 32$, and 177/33). Because the shoreline can exhibit seasonal variations, images from the same time of year were used [55]. The summer (or the periods close to summer) was suitable due to the atmospheric conditions [56].

\section{Image Preprocessing}

Landsat OLI images from 2013 were rectified using $1 / 25,000$ - and 1/100,000-scale topographic maps, and the images from 2000 and 1987 were registered image-toimage using the 2013 image. During these processes, the mean square error was maintained at less than 0.5 pixels. Because we used images from different sensors, digital numbers recorded by the Landsat TM, ETM+ and OLI sen-

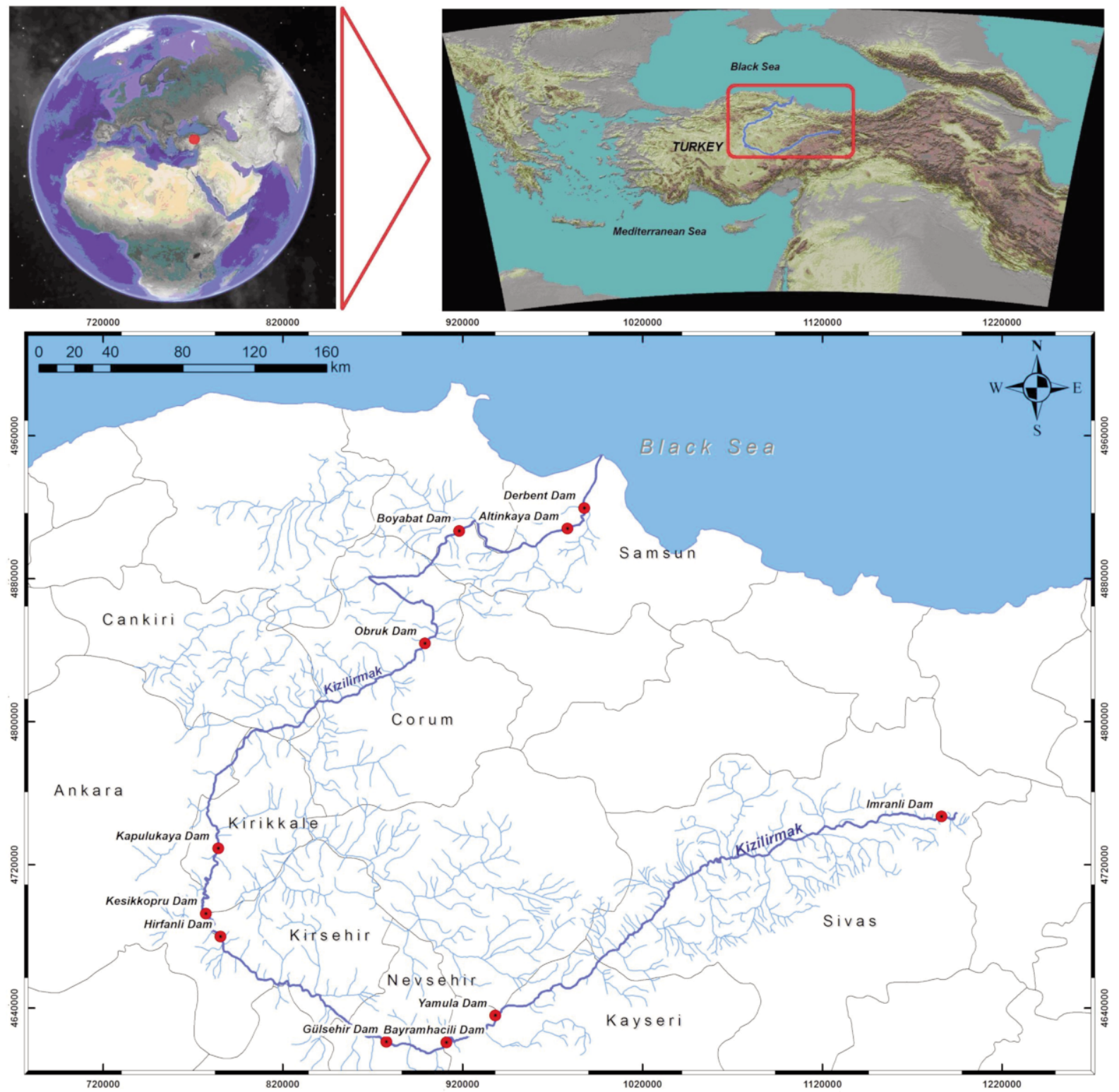

Fig. 1. The Kizilirmak River study area [53]. The lower figure shows the locations of the dams on the river. 


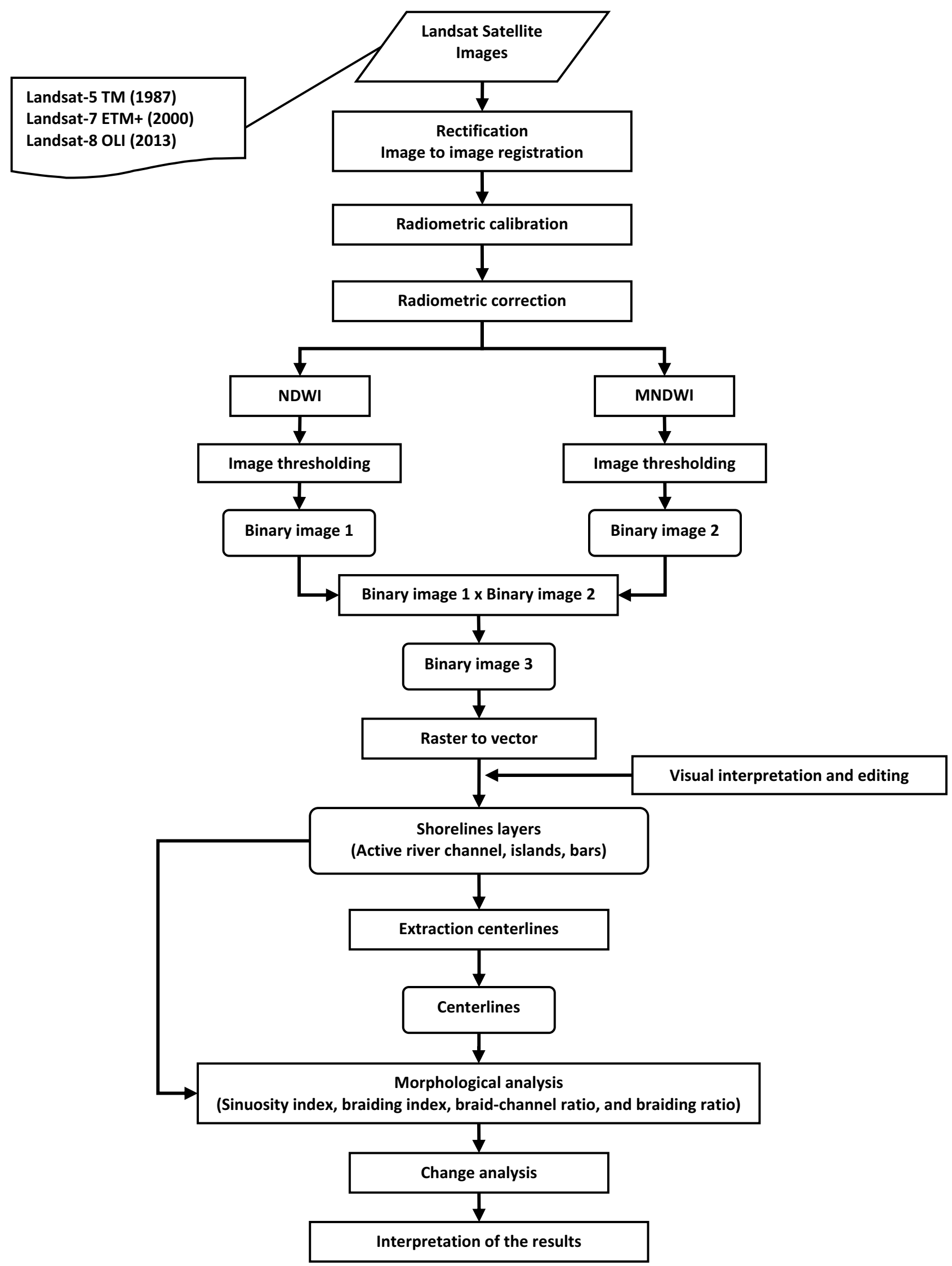

Fig. 2. Workflow chart that shows the main steps of the study. In the model, shorelines that were obtained by integrating the normalized difference water index (NDWI) and modified normalized difference water index (MNDWI) are transformed into vector form. Using the shorelines and the centerlines obtained from the shorelines, morphological analyses were conducted and changes were determined. 
sors were transformed into top of atmosphere (TOA) reflectance values. This normalization process substantially removes variations between the images from sensor differences, the Earth-sun distance and the solar zenith angle [5760]. The dark object subtraction (DOS) [61] model was applied to data that were converted to the TOA reflectance values for radiometric correction. The DOS model is one of the best methods for radiometric correction in changedetection studies. It is an entirely image-based method and does not require field measurements $[62,63]$.

\section{Determination of Shorelines}

To extract the shorelines, the NDWI (Eq. 1) [64] and the MNDWI (Eq. 2) [65] were used according to the workflow model presented in Fig. 2. The threshold values were applied to the NDWI and MNDWI images using control pixels from the images, and binary images were obtained by assigning values of 1 for land and 0 for water. The binary coded images were combined using the "AND" logical operator. Thus, the results of the NDWI index, which uses green and near-infrared (NIR) bands, and the MNDWI index, which uses green and midinfrared (MIR) bands, were integrated. The SWIR 1 bands of Landsat were used for MIR. Next, a raster-vector transformation was applied, and the shorelines (now in vector form) were edited using visual interpretation with various band combinations while making any necessary corrections. In the narrow river sections, the distinctiveness of the shorelines decreased, particularly in the images in which the river level was low, and the shorelines obtained from these sections required more editing. The edited shorelines were transformed into polygons and transferred to a database. Fig. 3 shows nearly $18 \mathrm{~km}$ of shorelines in vector form from a section in the river mouth in 1987 , 2000, and 2013.
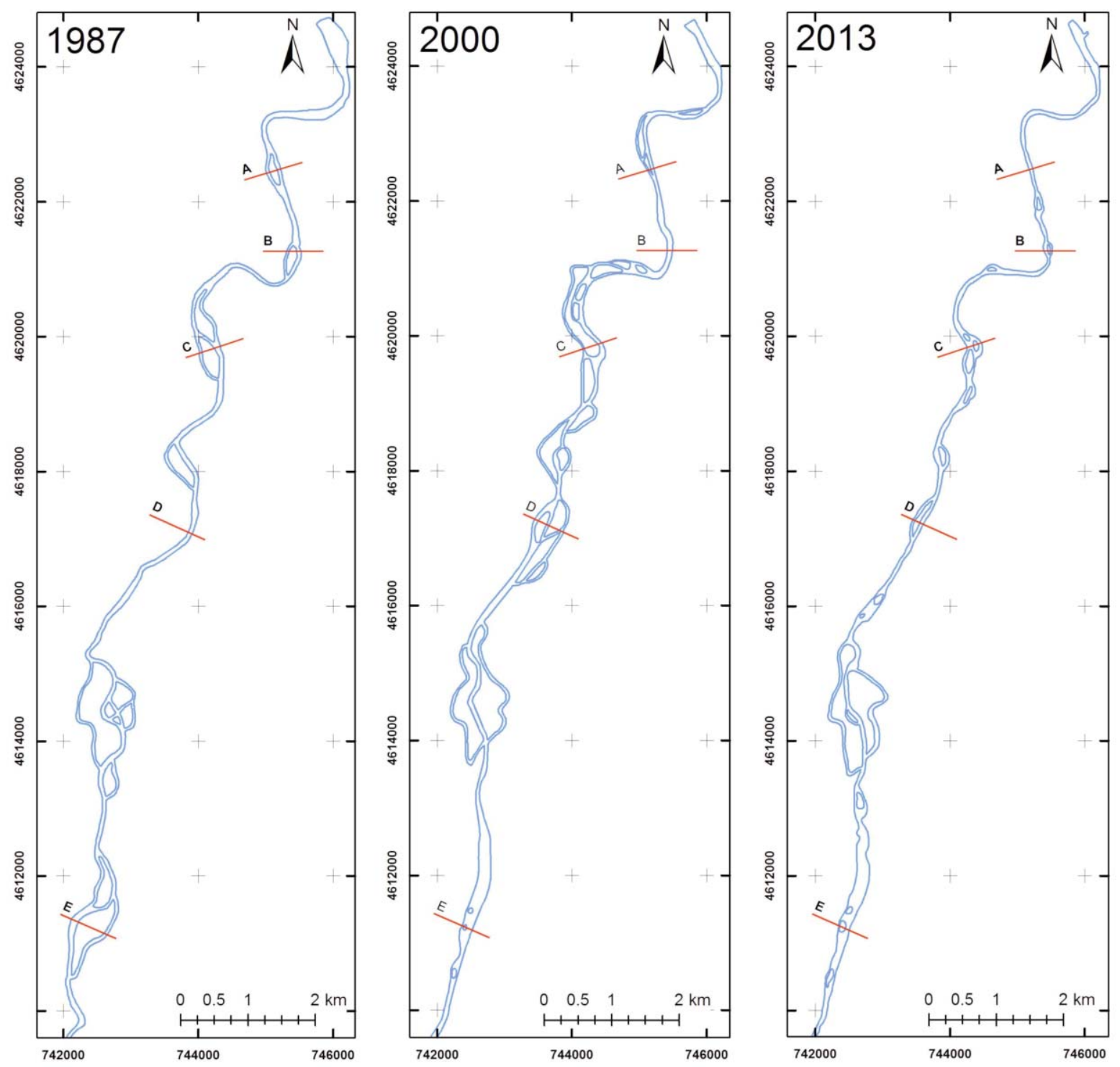

Fig. 3. Shorelines in vector form from a small section near the river mouth obtained from satellite images for 1987, 2000 , and 2013. The change in braiding is distinct in the section shown in the figure. Cross-sections A, B, C, D, and E generated perpendicular along the centerline of the river at the same $\mathrm{x}$, y positions reveal the dramatic changes in the river form over the years. 


$$
\begin{aligned}
\mathrm{NDWI} & =(\text { Green }-\mathrm{NIR}) /(\text { Green }+\mathrm{NIR}) \\
\mathrm{MNDWI} & =(\text { Green }-\mathrm{MIR}) /(\text { Green }+\mathrm{MIR})
\end{aligned}
$$

Centerlines were created from river channels in polygon form. The most important characteristic of the river centerlines is that the results do not change with changes in the water levels [18]. Therefore, the season in which the satellite image was collected should not create problems when measuring the centerline.

\section{Determination of the Sinuosity and Braiding Characteristics of the Kizilirmak River}

Numerous dams were built on the Kizilirmak River between 1987 and 2013. Braiding values are 0 in the reservoir area after the construction of a dam. For this reason, to perform the analysis more accurately and to investigate the downstream effects of dams on sinuosity and braiding, the river was analyzed in 21 sections according to the dam reservoirs for 1987, 2000, and 2013 (Fig. 4). The sections were numbered, with 1 corresponding to the upstream section and increasing toward the river mouth. The dams included in the sections and the years of construction are:

Section 2 - Imranli (2002),

Section 4 - Yamula (2005),

Section 6 - Bayramhacili (2011),

Section 8 - Gulsehir (2012),

Section 10 - Hirfanli (1959),

Section 11 - Kesikkopru (1966),

Section 13 - Kapulukaya (1989),

Section 15 - Obruk (2007),

Section 17 - Boyabat (2012),

Section 19 - Altinkaya (1987),

Section 20 - Derbent (1990) [53].

The sections corresponding to the dams in the analysis years are presented in Table 1.

To determine the sinuosity and braiding characteristics of the Kizilirmak River, the sinuosity index and three different braiding values were used. The sinuosity and braiding characteristics were used to define the channel pattern in the single channel and the multi-channel river structures [66].

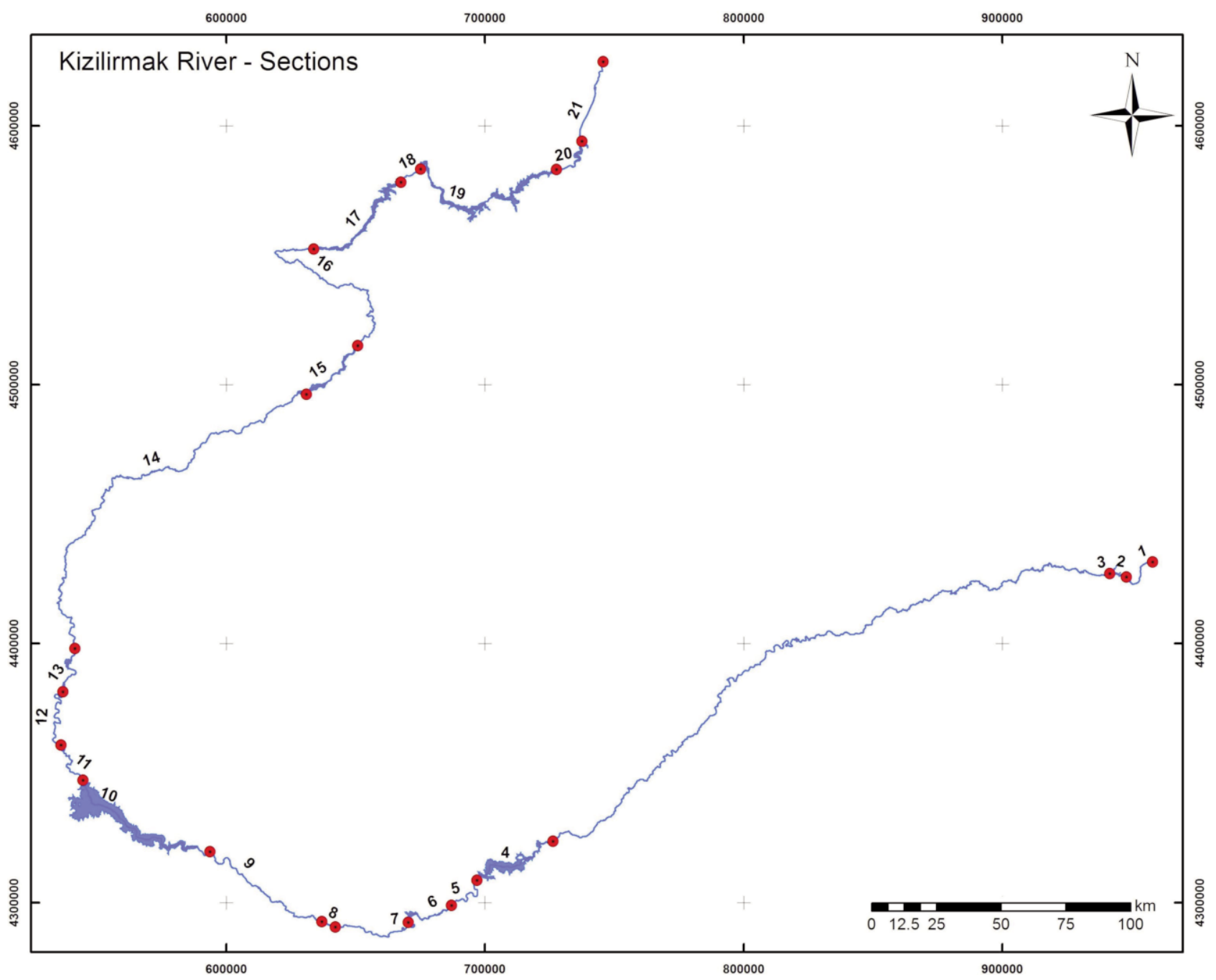

Fig. 4. Sections of the Kizilirmak River created for analysis. The 21 sections were numbered, with 1 corresponding to the upstream portion and values increasing toward the river mouth. 
Table 1. The existence of dams in 1987, 2000, and 2013 in the analysis sections (the presence of a dam reservoir in a section is indicated with an $\mathrm{x}$ ).

\begin{tabular}{|c|c|c|c|c|c|c|c|c|c|c|c|c|c|}
\hline \multirow{2}{*}{ Year } & \multicolumn{13}{|c|}{ Section No. } \\
\hline & 1 & 2 & 3 & 4 & 5 & 6 & 7 & 8 & 9 & 1 & & & 21 \\
\hline 1987 & & & & & & & & & & $\mathrm{x}$ & r & & \\
\hline 2000 & & & & & & & & & & $\mathrm{x}$ & & & \\
\hline 2013 & & $\mathrm{x}$ & & $\mathrm{x}$ & & $\mathrm{x}$ & &  & & $x$ & & & \\
\hline
\end{tabular}

The sinuosity index of a river is the ratio of the river's length measured along the thalweg line of the river to the horizontal distance between the start and end points of the channel in a reach of the river [67]. However, the thalweg line is related to the hydrography of the river and requires bathymetric measurements [66]. The sinuosity index, which was modified by Friend and Sinha [18], can be calculated by ratioing the centerline length of a major channel to the horizontal distance between the start and end points in the analyzed reach of the river (Eq. 3) [18]. Rivers with a sinuosity index of less than 1.5 are referred to as sinuous, whereas rivers with a sinuosity index above 1.5 are referred to as meandering [68]:

$$
S=\frac{L_{c \max }}{L_{0}}
$$

...where $L_{c \max }$ is the thalweg line or centerline length of the major channel between the start and end points, and $L_{0}$ is the horizontal distance between the start and end points.

In topographic maps, rivers are shown as single or dual lines depending on the scale of the map and the width of the river. In the GIS layer structure, rivers are shown as either lines or polygons (in wide rivers and large-scaled studies). To determine the river centerline from the river data that are represented as dual lines or as polygonal structures in the topographic maps in the GIS environment and to measure the river length accordingly, specific processes are required.

These processes are more complex in rivers that have more than one branch (rivers may transition between morphologies with single and multiple channels). In this case, it is important to determine the major channel [22]. In this study, the method suggested by Friend and Sinha [18] was used to determine the major channel centerlines from the rivers in polygon form, and the widest channel was accepted as the major channel in situations with multiple channels.

Braiding involves separating the river channel into more than one smaller channel and the reconnection of the separated channels [69]. Braided river channels are separated by islands and bars and exhibit multiple and complex channel structures [70]. Various parameters are defined for river braiding. The $B I$ [23], $B$ [18], and $B R$ [3] indexes used in this study are summarized below.

$B I$ is the ratio of the total length of the islands and bars in an examination section of the river to the horizontal distance between the start and end points of the channel in the section. Because most islands or bars (parallel to channel belt) are significantly greater in length than width, the total bank length is approximated by doubling the island or bar length $[18,23]$. Therefore, $B I$, originally proposed by Brice [23], was calculated as the ratio of twice the total length of the island and bars to the centerline of the riverbanks (Eq. 4) [1]:

$$
B I=2\left(\Sigma L_{i}\right) / L_{r}
$$

...where $\sum L_{i}$ is the total length of all islands and bars in the examination section of the river and $L_{r}$ is the centerline length between the banks of the channel belts in the examination section.

$B$ was calculated by taking the ratios of the lengths of all channels in the section to the length of the widest channel (Eq. 5) [1, 18]:

$$
B=L_{c t o t} / L_{c \max }
$$

Here, $L_{c t o t}$ is the sum of the centerline lengths of all segments in the examination section of the river and $L_{c \max }$ is the centerline length of the widest channel in the section [18].

$B R$ was calculated as the ratio of the total area of the islands and bars in the examination section of the river to the total channel area (Eq. 6) [3].

$$
B R=A_{b i} / A_{t c}
$$

Here, $A_{b i}$ is the total area of the islands and bars in the analyzed section of the river and $A_{t c}$ is the total channel area in the section.

In this study, the centerline between the right and left riverbanks was created for $B I$, and the centerline of the widest river channel was created to calculate $B$ and the sinuosity index. To accomplish this goal, points were created at $10-\mathrm{m}$ intervals on the shorelines in the GIS environment, and Thiessen polygons were created. A Thiessen polygon is a region surrounded by an embedded series of perpendicular bisectors, each located midway between the point under consideration and each of its neighbors [71]. Centerlines were calculated from the Thiessen polygons and were transferred to the database. These processes were repeated consecutively for 1987, 2000, and 2013. Moreover, the 
Table 2. The degrees of sinuosity and braiding.

\begin{tabular}{|c|c|c|}
\hline Degree & Sinuosity & Braiding and anastomosing \\
\hline 0 & - & $<5 \%$ \\
\hline 1 & $1-1.05$ & $5-34 \%$ \\
\hline 2 & $1.06-1.25$ & $35-65 \%$ \\
\hline 3 & $>1.26$ & $>65 \%$ \\
\hline
\end{tabular}

areas of islands and bars and the lengths of the islands and bars parallel to the river shore $\left(L_{i}\right)$ were calculated and transferred to the database as an attribute. The numbers of the sections to which these areas belonged were assigned to all data as an attribute, and the analyses were performed individually for each of the 21 sections.

To determine the sinuosity, points were created at $3-\mathrm{km}$ intervals on the centerline of the major channel to represent the sinuous characteristics of the river [72]. In addition, the start and end points of the dam reservoirs were marked.
The sinuosity was calculated for each piece, and the average values were calculated separately for each section.

The scale in Table 2 was used to determine the degrees of sinuosity and braiding. Braiding is a function of the relative abundances of bars and islands [73]. The degree of braiding is expressed quantitatively as the percentage of the channel length that contains islands or bars [74]. Thus, the half-values of the $B I$ were calculated, and the degrees of braiding were evaluated. The sinuosity index was used directly for the degree of sinuosity.

\section{Results}

The centerline lengths of the widest channel and the channel centerline lengths of the Kizilirmak River for 1987, 2000, and 2013, which were analyzed in 21 sections, are provided in Table 3. The total length of the centerline of the widest channel was $1,316.053 \mathrm{~km}$ in $1987,1,313.438 \mathrm{~km}$ in 2000 , and $1,292.462 \mathrm{~km}$ in 2013 . The total length of the channel centerline was $1,302.230$ in $1987,1,301.541$ in

Table 3. Change in the channel lengths for each section according to year.

\begin{tabular}{|c|c|c|c|c|c|c|}
\hline \multirow{2}{*}{ Section No. } & \multicolumn{3}{|c|}{ Centerline lengths of the widest channel $(\mathrm{km})$} & \multicolumn{3}{|c|}{ Centerline lengths (km) } \\
\hline & 1987 & 2000 & 2013 & 1987 & 2000 & 2013 \\
\hline Section 1 & 19.263 & 19.097 & 19.165 & 19.263 & 19.097 & 19.067 \\
\hline Section 2 & 7.985 & 7.920 & 7.591 & 7.985 & 7.920 & 7.591 \\
\hline Section 3 & 359.675 & 359.691 & 356.290 & 355.887 & 356.250 & 354.313 \\
\hline Section 4 & 54.167 & 53.758 & 43.028 & 53.561 & 53.166 & 43.662 \\
\hline Section 5 & 23.814 & 23.813 & 23.752 & 23.752 & 23.827 & 23.585 \\
\hline Section 6 & 24.145 & 24.237 & 23.985 & 24.145 & 24.240 & 23.985 \\
\hline Section 7 & 44.541 & 44.528 & 43.183 & 43.881 & 44.010 & 42.945 \\
\hline Section 8 & 6.508 & 6.835 & 6.228 & 6.464 & 6.730 & 6.228 \\
\hline Section 9 & 64.903 & 66.054 & 66.062 & 62.863 & 64.484 & 64.454 \\
\hline Section 10 & 70.964 & 71.276 & 71.727 & 70.964 & 71.276 & 71.727 \\
\hline Section 11 & 23.500 & 23.733 & 23.361 & 23.500 & 23.733 & 23.361 \\
\hline Section 12 & 40.812 & 40.647 & 40.537 & 40.318 & 39.765 & 39.943 \\
\hline Section 13 & 24.283 & 24.114 & 23.975 & 24.127 & 24.114 & 23.975 \\
\hline Section 14 & 203.670 & 205.684 & 209.286 & 201.201 & 202.170 & 203.202 \\
\hline Section 15 & 34.283 & 34.019 & 32.482 & 33.341 & 33.666 & 32.422 \\
\hline Section 16 & 98.168 & 98.670 & 99.230 & 97.904 & 98.679 & 98.802 \\
\hline Section 17 & 58.934 & 58.758 & 52.968 & 58.831 & 58.592 & 52.968 \\
\hline Section 18 & 11.345 & 11.021 & 11.247 & 11.164 & 10.791 & 10.998 \\
\hline Section 19 & 82.381 & 80.792 & 79.525 & 82.381 & 80.605 & 79.525 \\
\hline Section 20 & 23.450 & 22.674 & 22.638 & 23.413 & 22.674 & 22.638 \\
\hline Section 21 & 39.262 & 36.117 & 36.202 & 37.285 & 35.752 & 35.578 \\
\hline Total & $1,316.053$ & $1,313.438$ & $1,292.462$ & $1,302.230$ & $1,301.541$ & $1,280.969$ \\
\hline
\end{tabular}


Table 4. Brief statistical values of the sinuosity index for the Kizilirmak River in 1987, 2000, and 2013.

\begin{tabular}{|c|c|c|c|c|c|c|c|c|c|}
\hline \multirow{3}{*}{$\begin{array}{c}\text { Section } \\
\text { No. }\end{array}$} & \multicolumn{9}{|c|}{ Sinuosity } \\
\hline & \multicolumn{3}{|c|}{1987} & \multicolumn{3}{|c|}{2000} & \multicolumn{3}{|c|}{2013} \\
\hline & Mean & Max & Min & Mean & Max & Min & Mean & Max & Min \\
\hline Section 1 & 1.131 & 1.204 & 1.063 & 1.119 & 1.163 & 1.049 & 1.126 & 1.199 & 1.042 \\
\hline Section 2 & 1.220 & 1.399 & 1.093 & 1.201 & 1.241 & 1.169 & 1.159 & 1.217 & 1.045 \\
\hline Section 3 & 1.338 & 2.714 & 1.042 & 1.355 & 2.843 & 1.049 & 1.322 & 2.980 & 1.038 \\
\hline Section 4 & 1.313 & 1.646 & 1.030 & 1.297 & 1.625 & 1.026 & 1.167 & 1.468 & 1.016 \\
\hline Section 5 & 1.277 & 1.424 & 1.122 & 1.306 & 1.776 & 1.073 & 1.277 & 1.453 & 1.127 \\
\hline Section 6 & 1.163 & 1.233 & 1.089 & 1.156 & 1.262 & 1.084 & 1.123 & 1.242 & 1.036 \\
\hline Section 7 & 1.464 & 3.303 & 1.036 & 1.354 & 2.761 & 1.020 & 1.313 & 2.655 & 1.020 \\
\hline Section 8 & 1.240 & 1.417 & 1.063 & 1.201 & 1.423 & 1.056 & 1.091 & 1.119 & 1.046 \\
\hline Section 9 & 1.143 & 1.370 & 1.030 & 1.184 & 1.498 & 1.052 & 1.163 & 1.308 & 1.025 \\
\hline Section 10 & 1.117 & 1.532 & 1.006 & 1.106 & 1.694 & 1.011 & 1.122 & 1.521 & 1.006 \\
\hline Section 11 & 1.251 & 1.539 & 1.048 & 1.248 & 1.662 & 1.038 & 1.245 & 1.506 & 1.049 \\
\hline Section 12 & 1.455 & 2.134 & 1.052 & 1.419 & 2.111 & 1.070 & 1.451 & 2.149 & 1.061 \\
\hline Section 13 & 1.229 & 1.653 & 1.030 & 1.148 & 1.300 & 1.034 & 1.145 & 1.354 & 1.015 \\
\hline Section 14 & 1.237 & 1.954 & 1.040 & 1.242 & 2.162 & 1.027 & 1.263 & 1.698 & 1.028 \\
\hline Section 15 & 1.191 & 1.381 & 1.033 & 1.200 & 1.478 & 1.047 & 1.096 & 1.229 & 1.028 \\
\hline Section 16 & 1.194 & 1.496 & 1.032 & 1.221 & 1.807 & 1.027 & 1.249 & 2.084 & 1.022 \\
\hline Section 17 & 1.259 & 1.871 & 1.079 & 1.247 & 1.860 & 1.087 & 1.108 & 1.401 & 1.022 \\
\hline Section 18 & 1.182 & 1.321 & 1.096 & 1.159 & 1.420 & 1.013 & 1.205 & 1.519 & 1.045 \\
\hline Section 19 & 1.218 & 2.706 & 1.020 & 1.176 & 2.548 & 1.023 & 1.110 & 1.277 & 1.020 \\
\hline Section 20 & 1.290 & 1.496 & 1.055 & 1.225 & 1.423 & 1.025 & 1.221 & 1.386 & 1.020 \\
\hline Section 21 & 1.207 & 1.737 & 1.014 & 1.138 & 1.556 & 1.020 & 1.134 & 1.535 & 1.017 \\
\hline
\end{tabular}

2000, and 1,280.969 km in 2013. From Table 3, it is clear that the changes in the channel lengths between 2000 and 2013 were greater than the changes that occurred between 1987 and 2000.

The main statistical information regarding the sinuosity indexes for 1987, 2000, and 2013 is presented in Table 4. The highest average sinuosity was observed in the $7^{\text {th }}$ section, with a value of 1.464 in 1987 . In the $12^{\text {th }}$ section, values of 1.419 and 1.451 were observed in 2000 and 2013, respectively. The lowest average sinuosity was observed in the $10^{\text {th }}$ section, with a value of 1.117 in 1987 and 1.106 in 2000 . In the $8^{\text {th }}$ section, a value of 1.091 was observed in 2013.

The degree of sinuosity was determined for the $21 \mathrm{sec}$ tions using the scale in Table 2. In 1987, sections 1, 2, 6, 8, $9,10,11,13,14,15,16,18,19$, and 21 exhibited $2^{\text {nd }}$-degree sinuosity characteristics, whereas sections $3,4,5,7,12,17$, and 20 exhibited $3^{\text {rd }}$-degree sinuosity characteristics. In 2000 , sections $1,2,6,8,9,10,11,13,14,15,16,17$, $18,19,20$ and 21 exhibited $2^{\text {nd }}$-degree sinuosity character- istics, and sections 3, 4, 5, 7, and 12 exhibited $3^{\text {rd }}$-degree sinuosity characteristics. In 2013, sections $1,2,4,6,8,9$, $10,11,13,15,16,17,18,19,20$, and 21 exhibited $2^{\text {nd }}-$ degree sinuosity characteristics, and sections $3,5,7,12$, and 14 exhibited $3^{\text {rd }}$-degree sinuosity characteristics. Information regarding the total number of islands and bars and their areas is provided in Table 5. In 1987, the total number of islands and bars was 384, and the total area of the islands and bars was 2,023.457 ha. In 2000, the total number of islands and bars was 329 , and the total area of the islands and bars was 1,368.320 ha. In 2013, a total of 272 islands and bars were identified, with a total area of 1,252.334 ha. According to Table 5, 55 islands and bars were lost between 1987 and 2000. When sections 13 and 20 were excluded due to the construction of dams in these sections after 1987, 43 islands and bars were lost during this period. Between 2000 and 2013, 57 islands and bars were lost. When sections $2,4,6,8,15$, and 17 were excluded during this period (dams were built in these sections after 2000), 26 islands and bars were lost. The great- 
Table 5. Number of islands and bars and the areas of islands and bars in the Kizilirmak River in 1987, 2000, and 2013.

\begin{tabular}{|c|c|c|c|c|c|c|}
\hline Section No. & $\begin{array}{c}\text { Total number of } \\
\text { islands and bars } \\
\text { (1987) }\end{array}$ & $\begin{array}{l}\text { Total area of } \\
\text { islands and bars } \\
\text { (ha) (1987) }\end{array}$ & $\begin{array}{c}\text { Total number of } \\
\text { islands and bars } \\
\text { (2000) }\end{array}$ & $\begin{array}{l}\text { Total area of } \\
\text { islands and bars } \\
\text { (ha) (2000) }\end{array}$ & $\begin{array}{l}\text { Total number of } \\
\text { islands and bars } \\
\text { (2013) }\end{array}$ & $\begin{array}{l}\text { Total area of } \\
\text { islands and bars } \\
\text { (ha) (2013) }\end{array}$ \\
\hline Section 1 & 0 & 0.000 & 0 & 0.000 & 2 & 2.441 \\
\hline Section 2 & 0 & 0.000 & 0 & 0.000 & 0 & 0.000 \\
\hline Section 3 & 78 & 397.677 & 68 & 308.503 & 50 & 80.697 \\
\hline Section 4 & 14 & 36.228 & 11 & 26.509 & 0 & 0.000 \\
\hline Section 5 & 1 & 3.119 & 1 & 1.796 & 2 & 10.847 \\
\hline Section 6 & 0 & 0.000 & 2 & 1.646 & 0 & 0.000 \\
\hline Section 7 & 19 & 41.197 & 14 & 34.184 & 9 & 25.505 \\
\hline Section 8 & 5 & 21.054 & 3 & 14.453 & 0 & 0.000 \\
\hline Section 9 & 74 & 613.117 & 44 & 260.764 & 36 & 332.981 \\
\hline Section 10 & 0 & 0.000 & 0 & 0.000 & 0 & 0.000 \\
\hline Section 11 & 0 & 0.000 & 0 & 0.000 & 0 & 0.000 \\
\hline Section 12 & 18 & 53.908 & 24 & 61.881 & 23 & 66.753 \\
\hline Section 13 & 6 & 7.909 & 0 & 0.000 & 0 & 0.000 \\
\hline Section 14 & 100 & 420.587 & 113 & 414.482 & 106 & 613.459 \\
\hline Section 15 & 13 & 41.743 & 12 & 43.189 & 0 & 0.000 \\
\hline Section 16 & 11 & 21.767 & 3 & 5.900 & 6 & 8.248 \\
\hline Section 17 & 2 & 6.419 & 3 & 5.502 & 0 & 0.000 \\
\hline Section 18 & 3 & 12.532 & 3 & 10.117 & 2 & 8.478 \\
\hline Section 19 & 0 & 0.000 & 0 & 0.000 & 0 & 0.000 \\
\hline Section 20 & 6 & 65.432 & 0 & 0.000 & 0 & 0.000 \\
\hline Section 21 & 34 & 280.768 & 28 & 179.394 & 36 & 102.925 \\
\hline Total & 384 & $2,023.457$ & 329 & $1,368.320$ & 272 & $1,252.334$ \\
\hline
\end{tabular}

est changes in the total area of the islands and bars occurred in sections $3,9,14$, and 21 . The total areas of the islands and bars decreased in sections 3, 9, and 21, and increased in section 14 between 1987 and 2013.

In Table 6 , the $B I, B$, and $B R$ values are provided for 1987, 2000, and 2013 (the braiding value is 0 in sections that include dams, including sections 10, 11, 19 in 1987; sections 10, 11, 13, 19, 20 in 2000; and sections 2, 4, 6, 8, $10,11,13,15,17,19$, and 20 in 2013). The sections with no islands and bars have a braiding value of 0 , excluding the dam reservoir areas of 1,2, and 6 in 1987, and 1 and 2 in 2000.

The degrees of braiding were determined for the $21 \mathrm{sec}-$ tions using the scale in Table 2. In 1987, sections 5, 16, and 17 had a degree of 0 , sections $3,4,7,8,12,13,14,15,18$, and 20 exhibited 1st-degree braiding characteristics, and sections 9 and 21 exhibited 2nd-degree braiding characteristics. In 2000, sections 5, 6, 16, and 17 had a degree of 0 , sections $3,4,7,8,9,12,14,15$, and 18 exhibited $1^{\text {st }}$-degree braiding characteristics, and section 21 exhibited $2^{\text {nd }}$-degree braiding characteristics. In 2013, sections 1, 3, 5, and 16 had a degree of 0 , and sections $7,9,12,14,18$, and 21 exhibited $1^{\text {st }}$-degree braiding characteristics.

Considering sections $1,3,5,7,9,12,14,16,18$, and 21 together to determine the total effects of changes on the river revealed that the average sinuosity index was stable between 1987 and 2000 and between 2000 and 2013. However, the $B I$ braiding index gradually decreased. The weighted averages were calculated for the average sinuosity and average braiding. For the average values, the centerline lengths of the sections were accepted as weights. According to this method, the average sinuosity values were 1.283, 1.287, and 1.279 in 1987, 2000, and 2013, respectively, and the average $B I$ values were $0.324,0.252$, and 0.216 in 1987, 2000, and 2013, respectively.

\section{Discussion}

According to Fig. 5, which illustrates changes in the sinuosity index, an increase in sinuosity occurred in sections 3 , $5,9,14,15$, and 16 (a total of six sections) and a decrease 
Table 6. Braiding values of the Kizilirmak River in 1987, 2000, and 2013 (BI, B, and $B R$ ).

\begin{tabular}{|c|c|c|c|c|c|c|c|c|c|}
\hline \multirow{2}{*}{$\begin{array}{c}\text { Section } \\
\text { No. }\end{array}$} & \multicolumn{3}{|c|}{$B I=2\left(\sum L_{i}\right) / L_{r}$} & \multicolumn{3}{|c|}{$B=L_{c t o t} / L_{c \max }$} & \multicolumn{3}{|c|}{$B R=A_{b i} / A_{t c}$} \\
\hline & 1987 & 2000 & 2013 & 1987 & 2000 & 2013 & 1987 & 2000 & 2013 \\
\hline Section 1 & 0.000 & 0.000 & 0.048 & 0.000 & 0.000 & 0.066 & 0.000 & 0.000 & 0.039 \\
\hline Section 2 & 0.000 & 0.000 & 0.000 & 0.000 & 0.000 & 0.000 & 0.000 & 0.000 & 0.000 \\
\hline Section 3 & 0.180 & 0.155 & 0.073 & 0.233 & 0.202 & 0.104 & 0.163 & 0.121 & 0.040 \\
\hline Section 4 & 0.167 & 0.123 & 0.000 & 0.220 & 0.176 & 0.000 & 0.102 & 0.076 & 0.000 \\
\hline Section 5 & 0.043 & 0.027 & 0.084 & 0.053 & 0.035 & 0.114 & 0.023 & 0.013 & 0.075 \\
\hline Section 6 & 0.000 & 0.030 & 0.000 & 0.000 & 0.046 & 0.000 & 0.000 & 0.013 & 0.000 \\
\hline Section 7 & 0.256 & 0.193 & 0.133 & 0.350 & 0.276 & 0.171 & 0.130 & 0.108 & 0.080 \\
\hline Section 8 & 0.594 & 0.399 & 0.000 & 0.801 & 0.523 & 0.000 & 0.311 & 0.266 & 0.000 \\
\hline Section 9 & 1.352 & 0.659 & 0.623 & 1.465 & 0.772 & 0.782 & 0.471 & 0.355 & 0.386 \\
\hline Section 10 & 0.000 & 0.000 & 0.000 & 0.000 & 0.000 & 0.000 & 0.000 & 0.000 & 0.000 \\
\hline Section 11 & 0.000 & 0.000 & 0.000 & 0.000 & 0.000 & 0.000 & 0.000 & 0.000 & 0.000 \\
\hline Section 12 & 0.290 & 0.356 & 0.366 & 0.403 & 0.492 & 0.504 & 0.134 & 0.135 & 0.183 \\
\hline Section 13 & 0.103 & 0.000 & 0.000 & 0.158 & 0.000 & 0.000 & 0.033 & 0.000 & 0.000 \\
\hline Section 14 & 0.348 & 0.355 & 0.390 & 0.510 & 0.510 & 0.528 & 0.177 & 0.190 & 0.283 \\
\hline Section 15 & 0.218 & 0.226 & 0.000 & 0.336 & 0.333 & 0.000 & 0.129 & 0.148 & 0.000 \\
\hline Section 16 & 0.059 & 0.016 & 0.021 & 0.085 & 0.023 & 0.038 & 0.033 & 0.011 & 0.015 \\
\hline Section 17 & 0.030 & 0.026 & 0.000 & 0.039 & 0.039 & 0.000 & 0.018 & 0.015 & 0.000 \\
\hline Section 18 & 0.191 & 0.170 & 0.145 & 0.269 & 0.246 & 0.193 & 0.159 & 0.138 & 0.105 \\
\hline Section 19 & 0.000 & 0.000 & 0.000 & 0.000 & 0.000 & 0.000 & 0.000 & 0.000 & 0.000 \\
\hline Section 20 & 0.360 & 0.000 & 0.000 & 0.453 & 0.000 & 0.000 & 0.265 & 0.000 & 0.000 \\
\hline Section 21 & 1.033 & 0.827 & 0.579 & 1.164 & 0.946 & 0.812 & 0.406 & 0.324 & 0.228 \\
\hline
\end{tabular}

occurred in the other sections between 1987 and 2000. Furthermore, an increase occurred in sections 1, 10, 12, 14, 16 , and 18 (a total of six sections) and a decrease occurred in the other sections between 2000 and 2013. The greatest increase between 1987 and 2000 occurred in section 9 (0.041), and the greatest decrease occurred in section 7
(-0.110). The greatest increase between 2000 and 2013 occurred in section 18 (0.046), and the greatest decrease occurred in section 17 (-0.139). Fig. 5 also shows that the changes in the sinuosity index between 2000 and 2013 were greater than the changes that occurred between 1987 and 2000 .

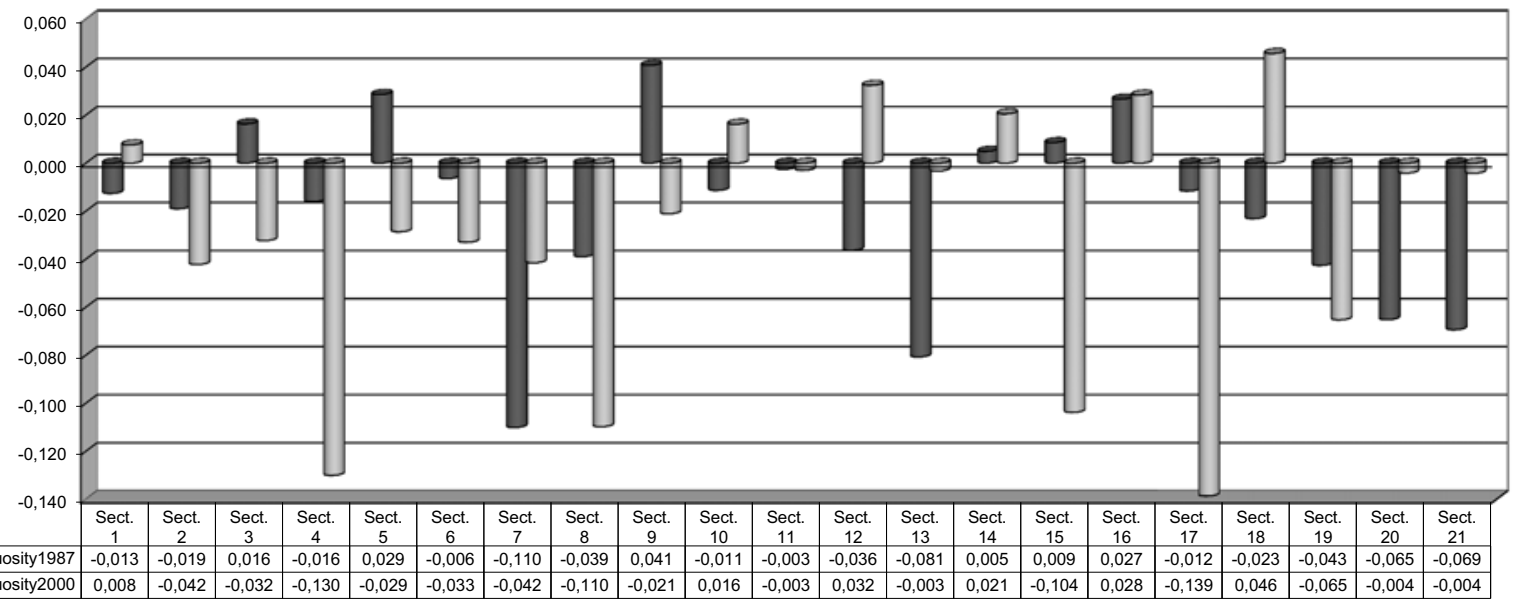

Fig. 5. Graph of the sinuosity index changes for 1987-2000 and 2000-13. 
Between 1987 and 2000, an increase in the $B I, B$, and $B R$ values in sections 6 and 12 occurred. However, the $B I$, $B$, and $B R$ values decreased in sections $3,4,5,7,8,9,13$, 16, 18, 20, and 21 (Fig. 6). In section 15, the $B I$ and $B R$ braiding values increased, and the $B$ value decreased. The $B I$ and $B R$ values increased in section 14 and decreased in section 17 . However, the $B$ value did not change in sections 14 and 17.

Between 2000 and 2013, the $B I, B$, and $B R$ values in sections $1,5,12,14$, and 16 increased (a total of five sections), and the $B I, B$, and $B R$ values in sections $3,4,6,7,8$, $15,17,18$, and 21 decreased. In section 9 , the $B$ and $B R$ values increased, and the $B I$ value decreased (Fig. 6).

The braiding values of sections 1 and 2 were both 0 in 1987 and 2000. Because dams were constructed in sections 10,11 , and 19 in 1987, 2000, and 2013, their braiding values were 0. In addition, because dams were built after 1987 in sections 13 and 20, the braiding values of these sections were 0 in 2000 and 2013. Because dams were built after 2000 in sections $2,4,6,8,15$, and 17 , their braiding values were 0 in 2013.

The maximum changes in $B I$ between 1987 and 2000 occurred in sections 9, 20, and 21. Between 2000 and 2013, the maximum changes occurred in sections 8,21 , and 15 . The maximum changes in $B$ between 1987 and 2000 occurred in sections 9, 20, and 8. Between 2000 and 2013, the maximum changes occurred in sections 8,15 , and 4 . The maximum changes in $B R$ between 1987 and 2000 occurred in sections 20,9, and 21. In addition, between 2000 and 2013, the maximum changes occurred in sections 8,15 , and 21 (Fig. 6). The maximum changes were in the direction of decreased braiding.

Fig. 7 presents a comparison of $B I, B$, and $B R$. Similar results were obtained for $B I$ and $B$. Furthermore, the results of all three indexes $(B I, B, B R)$ were generally consistent with each other. The interval scale (the difference between

a)

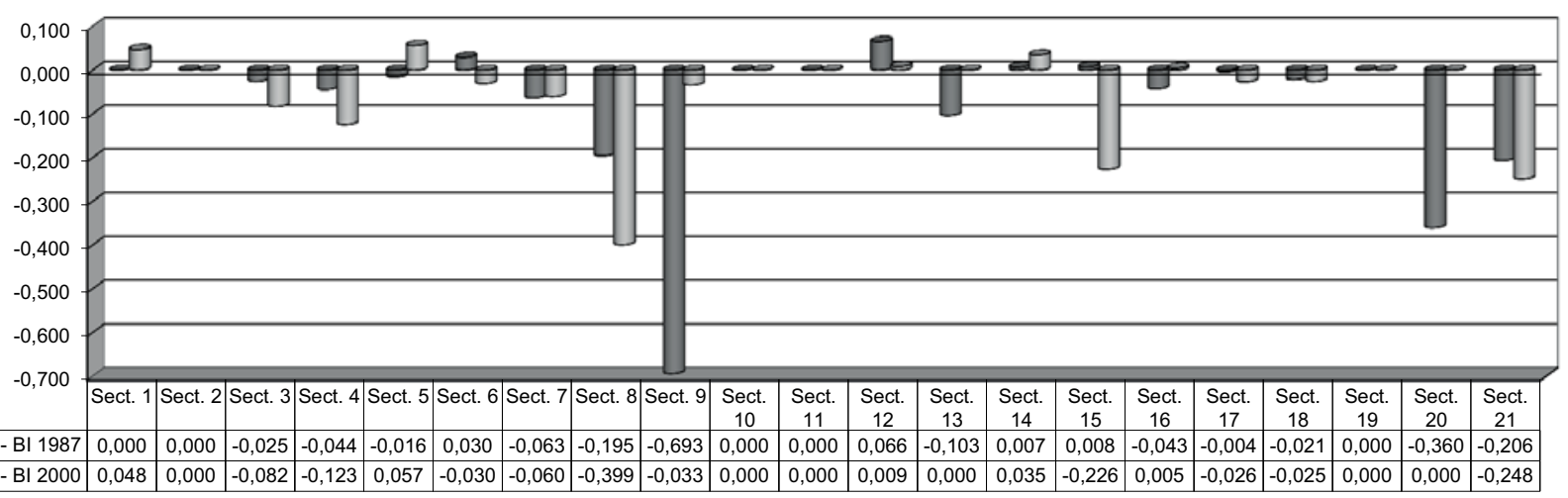

b)

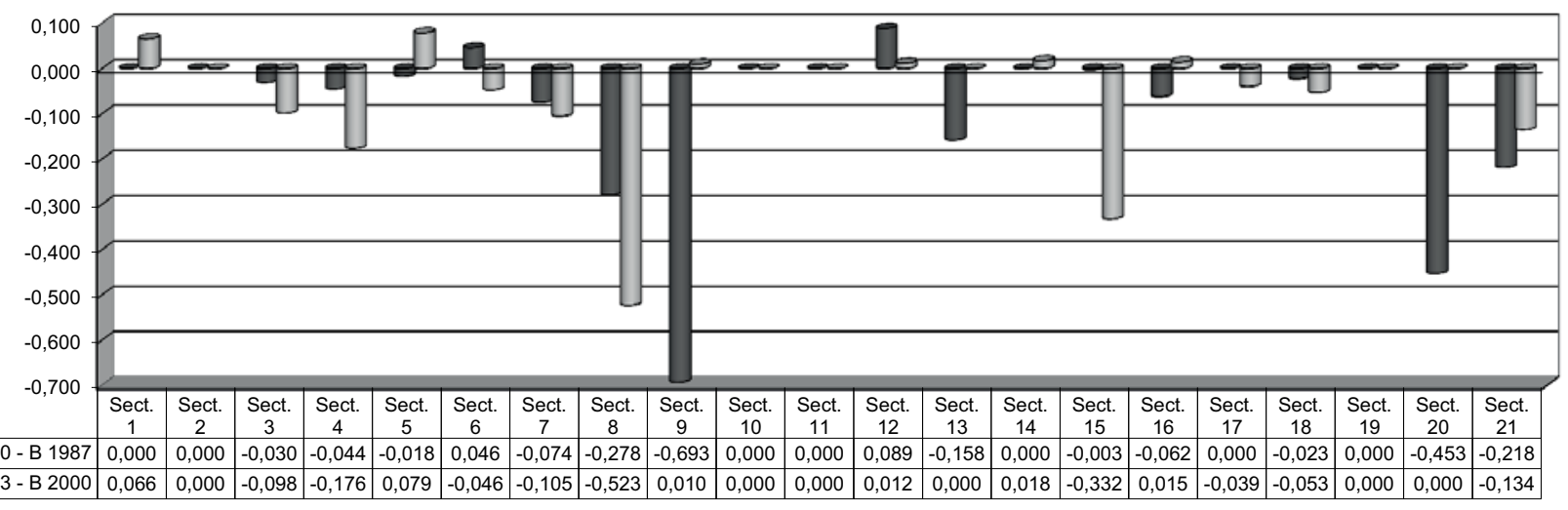

c)

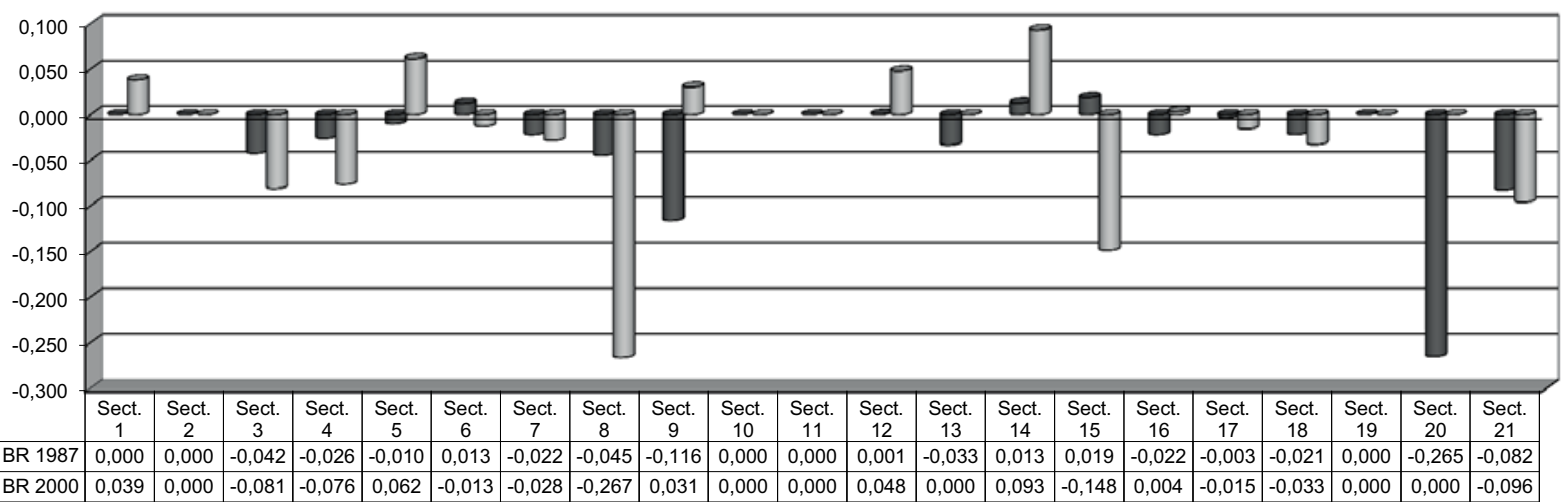

Fig. 6. Braiding change graphic for 1987-2000 and 2000-13. (a) Change in the braiding index, (b) change in the braid channel ratio, and (c) change in the braiding ratio. 
the minimum and maximum values) was 1.322 for $B I, 1.424$ for $B$, and 0.452 for $B R$ in $1987 ; 0.811$ for $B I, 0.923$ for $B$, and 0.344 for $B R$ in 2000; and 0.602 for $B I, 0.774$ for $B$, and 0.370 for $B R$ in 2013 ("O" braiding values were excluded from this assessment). These values indicate that the interval scale for $B$ is wider than those for $B I$ and $B R$ (Table 6).

To determine the relationship between the sinuosity and braiding changes, comparisons were made for 1987-2000 and 2000-13 (because the braiding value is 0 in sections where there are dams, these sections were excluded from these comparisons). Sections 1, 2, 3, 4, 5, 6, 7, 8, 9, 12, 14, $15,16,17,18$, and 21 were evaluated for changes between 1987 and 2000, and sections 1, 3, 5, 7, 9, 12, 14, 16, 18, and 21 were evaluated for changes from 2000 to 2013.
The changes in the sinuosity and $B I$ braiding indexes between 1987 and 2000 and between 2000 and 2013 are presented in Fig. 8.

According to Fig. 8, the sinuosity increased and braiding decreased in sections $3,5,9$, and 16 , and the sinuosity decreased and braiding increased in sections 6 and 12 between 1987 and 2000. The sinuosity and braiding both increased in sections 14 and 15, and the sinuosity and braiding both decreased in sections 4, 7, 8, 17, 18, and 21 . Between 2000 and 2013, the sinuosity increased and braiding decreased in section 18, and the sinuosity decreased and braiding increased in section 5 . Both sinuosity and braiding increased in sections $1,12,14$, and 16 , and both sinuosity and braiding decreased in sections $3,7,9$, and 21 .
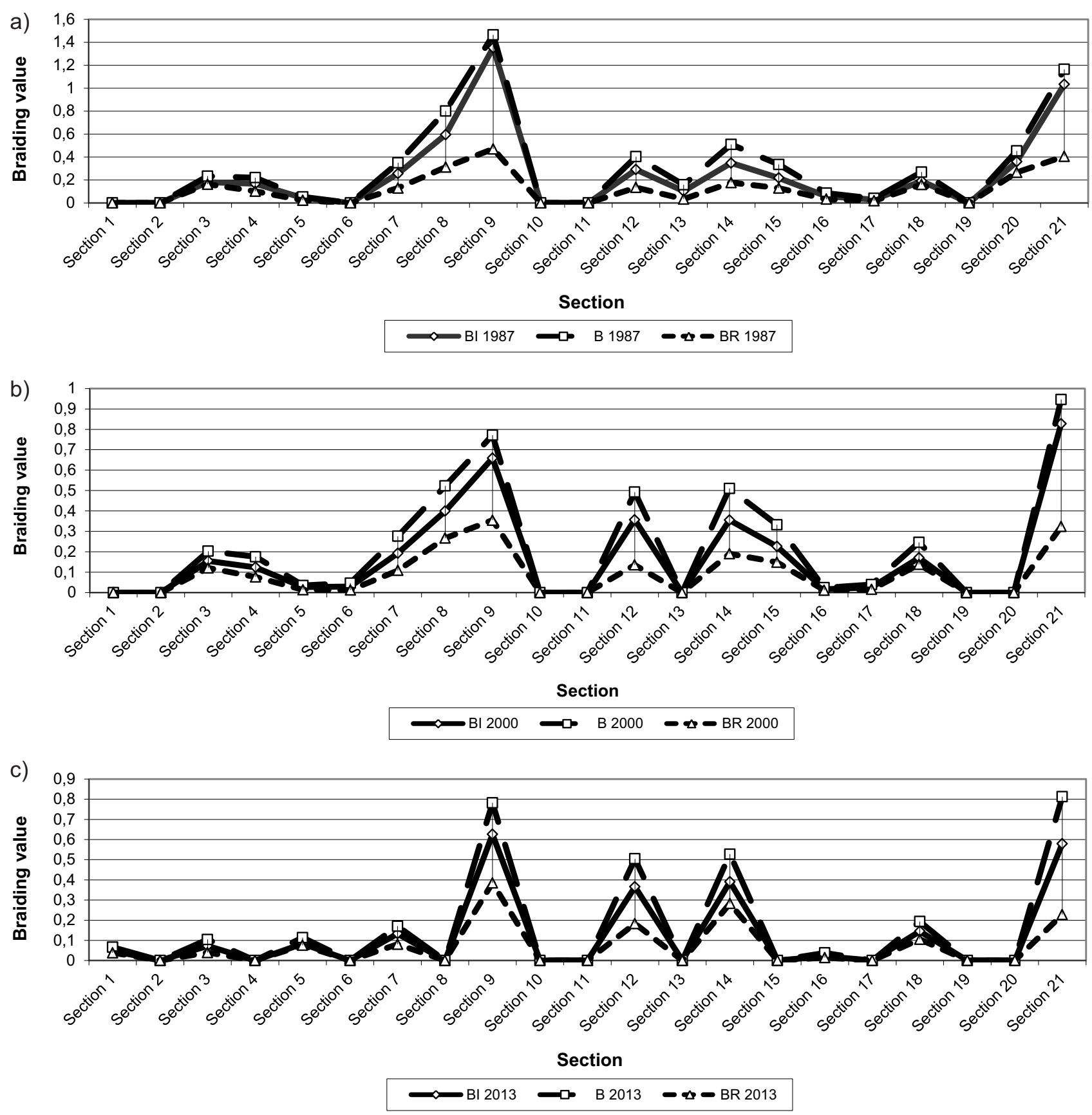

Fig. 7. Comparison of the braiding index, braid channel ratio, and braiding ratio. (a) 1987, (b) 2000, and (c) 2013. 
According to these results, the sections of the Kizilirmak River experienced different change trends between 1987 and 2000 and between 2000 and 2013. In addition to the changes that resulted from natural changes, a great deal of human intervention occurred on the Kizilirmak. The integrated effects of natural changes and changes due to human activities, including the construction of 11 dams, sand and gravel acquisition from the riverbed, and river improvements, altered the planform characteristics of the Kizilirmak River. Alluvial material carried by rivers is very important for shaping the formation of riverbeds, islands, and bars [3]. After the construction of the dams, the flow rate of the Kizilirmak River decreased, and sediment flow was interrupted. The amount of sediment carried by the Kizilirmak River was 23.1 million tons/year before the dams were constructed. This amount decreased to 18 million tons/year after the construction of the Hirfanli Dam (1959), and dropped to 0.46 million tons/year after the construction of the Altinkaya (1987) and Derbent (1990) Dams [35]. The changes in the sediment amount and the flow rate affected the riverbed slope [3, 75]. In addition, uncontrolled sand and gravel extractions from the riverbed caused deep excavations in the riverbed. Accordingly, the thalweg elevations decreased in those regions (the Kizilirmak River experienced a decline of up to $10 \mathrm{~m}$ in the elevation of the thalweg). Consequently, the river equilibrium profile changed, and morphological changes in the river occurred $[41,76]$. In addition, the riverbed arrangements changed the river planform [34].

Sinuosity and braiding both decreased in most of the sections downstream of the dams (Section 21 for 19872000; Sections 3, 7, 9, and 21 for 2000-13). The interruption of sediment flow after dam construction greatly prevented the formation of new islands and bars, and current islands and bars shrunk or were lost. Although an increase in the sinuosity was expected in the downstream sections of the dams depending on the decrease in the flow rate and riverbed slope, many of the downstream sections exhibited a decrease in sinuosity. This effect proved that other factors - including sand and gravel extraction and riverbed regulations - affect the river planform.

Several studies have reported results similar to our findings. Zeybek et al. [41] stated that the Kizilirmak riverbed changed at the estuary of the river and in the southern part of it. The river had numerous short curves in 1956, but

a)

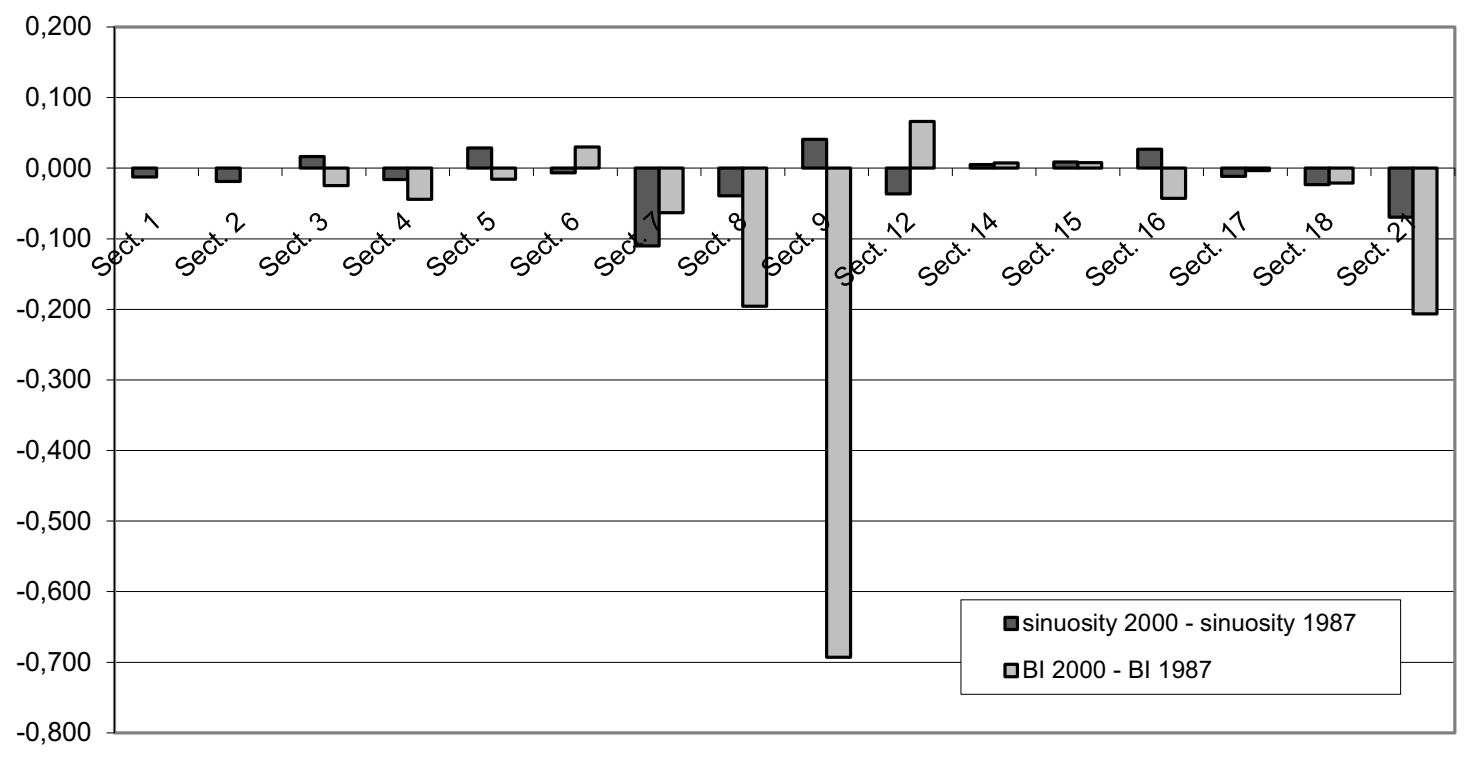

b)

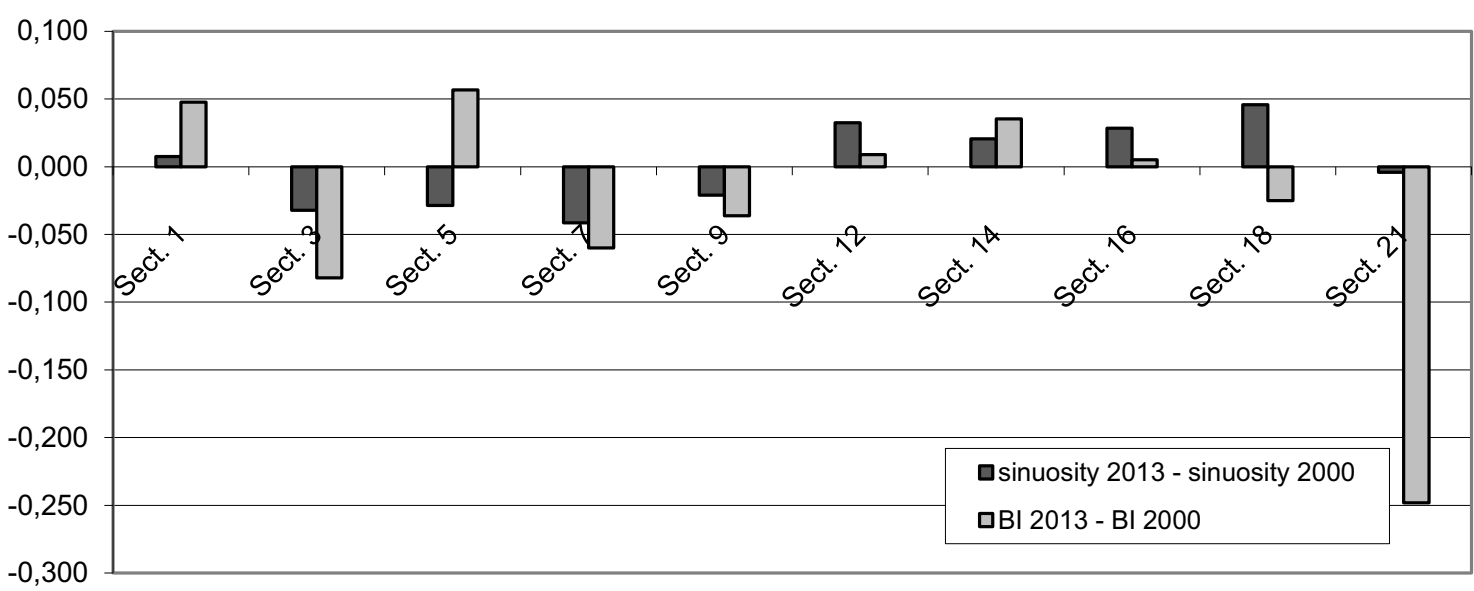

Fig. 8. Changes in the sinuosity and BI braiding indexes between 1987-2000 and 2000-13. 
fewer, larger radius curves today. Zeybek et al. also indicated that an island (2.5 ha) at approximately $150 \mathrm{~m}$ south of the estuary of the river was lost. Sertel et al. [77] demonstrated that while the Kizilirmak River had a wide and curvilinear form in 1987, the river form changed and became narrow and linear in form in 2004 downstream of the Derbent Dam. The Scientific and Technological Research Council of Turkey [76] stated that extraction of sand and gravel caused the changes in the Kizilirmak riverbed and deterioration of the flow system, and the riverbanks began to flatten because of the bank erosion. The area examined in Zeybek et al. and Sertel et al. corresponds to Section 21 in our study. In our study, decreases in sinuosity and braiding were observed in this section, consistent with the studies mentioned above.

Because most of the sand and gravel extraction activities were illegal and uncontrolled, it was not possible to make a determination based on the spatial data for those regions. In addition, clear information on the number, reserves, and production of sand and gravel quarries in Turkey is unfortunately not available [76]. However, the negative impacts of dozens of sand and gravel quarries on the Kizilirmak River have been described in many studies [35, 37, 39, 41, 76, 77]. Among these studies, Ayan [37] stated that the total material extracted from a $16-\mathrm{km}-$ long section downstream of Derbent Dam (in Section 21 in this study) was approximately $17,600,000 \mathrm{~m}^{3}$ (up to 2002). The value of a small section of the river provides an important clue about sand and gravel extraction throughout the river.

The factors that caused the changes in the sinuosity and braiding of the river also affect the sea coast and whole ecosystem. Because of dams and sand and gravel extraction activities, the amount of sediment carried by the river to the sea decreased, and deterioration around estuaries and coastal erosion occurred [31, 35, 37]. In the section where the river flows into the Kizilirmak, Bafra Delta Plain was covered by the sea, and a large amount of fertile soil was lost. Extracting uncontrolled and excessive amounts of sand and gravel from the riverbed threatened dams and bridges [37]. After the danger experienced with the Altinkaya and Derbent Dams, sand and gravel extraction in the Kizilirmak Delta and near dams and bridges throughout the river was prohibited in 2002.

In addition, uncontrolled sand and gravel extraction disturbed water flow and direction. Increasing the water flow rate caused material transport and filling of the dam reservoir, thus shortening the lives of the dams. The deterioration of the riverbed also caused flooding problems in some residential areas; consequently, several flood protection structures and riverbed arrangements have been constructed in some areas [34]. The reduction and disruption of gravel in the river (fish spawning grounds) disrupted the fish habitat and all aquatic organisms [76, 77]. Thus, the changes in the river affect not only the river but also all environmental conditions and disrupt ecological life.

Although sand and gravel extraction from the riverbed in the Kizilirmak Delta has been prohibited, illegal sand and gravel extraction from the delta coast and riverbed has continued $[36,37,76]$. Most sand and gravel extraction is cur- rently concentrated around Nevsehir, Kayseri, and Kirsehir. A large portion of the sand and gravel needs of Turkey are met from the Kizilirmak riverbed. Consequently, necessary measures should be taken to prevent the collection of sand and gravel. Unlicensed and uncontrolled extraction should be avoided, and the amount of sand and gravel removed should be regulated. Sand and gravel extraction should be allowed up to a certain level below the river bed or thalweg, or up to a safe percentage of sediments carried by the river [76].

The results of this study are in agreement with the results of the study conducted by Gorendagli [3] on the Kizilirmak River. In the study conducted by Gorendagli which was performed using maps and aerial photographs of a section of the Kizilirmak River between the Sarihidir and Ciftedam districts (connected to Avanos and Nevsehir) the sinuosity value was 1.1 and the $B R$ value was 0.10 in 1954; the sinuosity value was 1.1 and the $B R$ value was 0.03 in 2009. In this study, section 7 generally corresponds to the study area of Gorendagli [3]. The $B R$ value in section 7 was 0.13 in 1987, 0.11 in 2000, and 0.08 in 2013. The average sinuosity values in section 7 were 1.46 in 1987, 1.35 in 2000, and 1.31 in 2013. Thus, both studies indicate that sinuosity and braiding decreased in section 7 of the Kizilirmak River. Based on the comparisons made with the study using aerial photographs and maps, the Landsat TM/ETM+/OLI images have great potential for determining sinuosity and braiding. However, Landsat images are subject to a mixed pixel problem, which negatively affects the analysis [78]; the use of higher-resolution satellite images will increase the accuracy of the results.

\section{Conclusions}

Sinuosity and braiding can differ for each river. Similarly, sinuosity and braiding may exhibit different characteristics in different sections of a river. Natural and manmade factors cause changes in the sinuosity and braiding characteristics of a river over time. The Kizilirmak River has experienced important hydromorphological changes due to natural conditions and human intervention over time. In this study, short-term changes in the Kizilirmak River were examined using Landsat TM/ETM+/OLI satellite images from 1987, 2000, and 2013. The study area was analyzed by dividing the river into 21 sections. An increase in the sinuosity index occurred in sections $3,5,9,14,15$, and 16 , and a decrease in the other sections occurred in the 1987-2000 period. The sinuosity increased in sections 1 , $10,12,14,16$, and 18 and decreased in the other sections in the $2000-13$ period. In this study, three different braiding parameters were evaluated. The $B I, B$, and $B R$ values increased in sections 6 and 12 and decreased in sections 3, $4,5,7,8,9,13,16,18,20$, and 21 in the 1987-2000 period. The $B I, B$, and $B R$ values increased in sections $1,5,12,14$, and 16 , and decreased in sections $3,4,6,7,8,15,17,18$, and 21 in the $2000-13$ period.

The results of this study indicate that the changes in the hydrological and riverbed topographic conditions caused 
the pattern changes in the 1987-2000 and 2000-13 periods. Dams and the extraction of sand and gravel have very important effects on river flow regimes and sediment transport. As a natural consequence of uncontrolled dam construction and sand and gravel extraction, the flow and pattern of the river changed. Coasts and ecosystems were affected by these changes. Nature is the common heritage of humanity, and compensation for environmental damage is difficult. Therefore, the construction of dams and the extraction of sand and gravel from the riverbed should be conducted using planned scientific methods.

In this study, the use of remote sensing and GIS provided many advantages. GIS allowed the data to be analyzed rapidly and accurately, and the data analysis results could be stored digitally for future studies. The Kizilirmak River is a long river. However, the entire river was analyzed within the scope of this study. It is impossible to evaluate such a large area using traditional methods due to the expense and large amounts of time required. Considering the size of the study area, the spatial resolution of the Landsat images was sufficient. This mid-resolution study, which covers a large area, has gathered primary information for determining critical areas in further studies. The progressive evaluation of one site instead of generating data at high cost for the entire area of large sites would be a more effective approach. In other words, initial general studies to evaluate the entire area should be followed by high-resolution studies of areas that require more detailed study.

This study is important for presenting the planform characteristics of the Kizilirmak River and the potential of Landsat images for determining the sinuosity and braiding characteristics of rivers. In developing countries, the deficiencies and insufficiencies of spatial data are an important problem. Satellite images provide an important alternative, both economically and rapidly and for generating data.

The results of this study can be used to predict potential future changes and to evaluate the current conditions of the Kizilirmak River. The factors that have caused changes in the river channel planform over the 26-year study period may lead to significant long-term changes. Therefore, revealing current changes and investigating their causes are advantageous when planning and managing river and environmental conditions

\section{Acknowledgements}

This study was supported by the Ondokuz Mayis University Scientific Research Projects Commission (Project Code: PYO.MUH.1901.13.001).

\section{References}

1. O'NEILL B. J., THORP J. H. A simple channel complexity metric for analyzing river ecosystem responses. River Syst. 19, (4), 327, 2011.

2. SINHA R., JAIN V., BABU G. P., GHOSH S. Geomorphic characterization and diversity of the fluvial systems of the Gangetic Plains. Geomorphology 70, (3-4), 207, 2005.
3. GORENDAGLI N. A. The changes that observed in channel type of the Kizilirmak River between 1954 and 2009 years, Avanos. Turk. J. Geogr. Sci. 8, (1), 93, 2010 [In Turkish].

4. OZSAHIN E., EKINCI D. Meandering morphology of Gonen Creek and factors affecting meandering. Turk Cogr. Derg. 62, 39, 2014 [In Turkish].

5. ALESHEIKH A. A., GHORBANALI A., NOURI N. Coastline change detection using remote sensing. Int. J. Environ. Sci. Te. 4, (1), 61, 2007.

6. ALAM J. B., UDDIN M., AHMED J. U., RAHMAN M. H., BANIK B. K., YESMIN N., ISLAM M. S. Study of the morphological change of the river old Brahmaputra and its impacts. Asian J. Water Environ. Pollut. 6, (1), 11, 2009.

7. CHORLEY R. J., SCHUMM S. A., SUGDEN D. E. Geomorphology. Methuen: London, 1984.

8. GORDON N. D., MCMAHON T. A., FINLAYSON B. L., GIPPEL C. J., NATHAN R. J. Stream Hydrology: An Introduction for Ecologists. John Wiley \& Sons: Chichester, 2004.

9. OTTAWA RIVER HERITAGE DESIGNATION COMMITTEE. A Background Study for Nomination of the Ottawa River Under the Canadian Heritage Rivers System. QLF Canada, 2005.

10. SEKER D. Z., KAYA S., MUSAOGLU N., KABDASLI S., YUASA A., DURAN, Z. Investigation of meandering in Filyos River by means of satellite sensor data. Hydrol. Process. 19, 1497, 2005.

11. NICHOLS G. Sedimentology and Stratigraphy. Wiley \& Blackwell: Chichester, 9, 2009.

12. BERNAL C., CHRISTOPHOUL F., DARROZES J., LARAQUE A., BOURREL L., SOULA J. C., GUYOT J. L., BABY P. Crevassing and capture by floodplain drains as a cause of partial avulsion and anastomosis (lower Rio Pastaza, Peru). J. S. Am. Earth Sci. 44, 63, 2013.

13. ASHWORTH P. J., LEWIN J. How do big rivers come to be different. Earth-Sci. Rev. 114, (1-2), 84, 2012.

14. WISEMAN D. J. Braiding.

http://wiseman.brandonu.ca/Lecture\%20Notes/geomorph/ Presentations/GeomorphMeanderingBraiding.pptx (Accessed 08 September 2012).

15. YURUR M. T. Physical Geology-II Lecture notes. http://yunus.hacettepe.edu.tr/ tyurur/Fizikjeoloji.htm (Accessed 18 September 2014) [In Turkish].

16. YONECHI F., MAUNG W. Subdivision on the Anastomosing River Channel with a Proposal of the Irrawaddy Type. The Science Reports of the Tohoku University, $7^{\text {th }}$ Series (Geography), 36, (2), 102, 1986.

17. LEIGH D. S., SRIVASTAVA P., BROOK G. A. Late Pleistocene braided rivers of the Atlantic coastal plain, USA. Quaternary Sci. Rev. 23, (1-2), 65, 2004.

18. FRIEND P. F., SINHA R. Braiding and Meandering Parameters. Geological Society, London, Special Publications, 75, (1), 105, 1993.

19. BABAR M. Hydrogeomorphology: Fundamentals, Applications and Techniques. New India Publishing Acency: New Delhi, 2005

20. HASFURTHER V. R. The use of meander parameters in restoring hydrologic balance to reclaimed stream beds. In The Restoration of Rivers and Streams Theories and Experience. Gore, J. A., Ed., Butterworth: Boston, pp. 21-40, 1985.

21. ARMAS I., NISTORAN D. E. G., OSACI-COSTACHE G., BRASOVEANU L. Morpho-dynamic evolution patterns of Subcarpathian Prahova River (Romania). Catena 100, 83, 2012. 
22. ZHANG L., HUANG W., JIANG J. Calculating river length based on topographic data. The International Archives of the Photogrammetry, Remote Sensing and Spatial Information Sciences, XXXVII (Part B4), 181, 2008.

23. BRICE J. C. Channel Patterns and Terraces of the Loup Rivers in Nebreska. United States Geological Survey Professional Papers, 422-D, 1964.

24. CARBONNEAU P., PIEGAY H. Fluvial Remote Sensing for Science and Management-Advancing River Restoration and Management. Wiley \& Sons: Chichester, 2012.

25. DURAN Z., MUSAOGLU N., SEKER D. Z. Evaluating urban land use change in historical peninsula, Istanbul, by using GIS and remote sensing. Fresen. Environ. Bull. 15, (8a), 806, 2006

26. EL-ASMAR H. M., HEREHER M. E., EL-KAFRAWY S. B. Surface area change detection of the Burullus Lagoon, North of the Nile Delta, Egypt, using water indices: A remote sensing approach. Egypt. J. Remote Sens. Space Sci. 16, (1), 119, 2013.

27. KAYA S., SERTEL E., SEKER D. Z., TANIK A. Multitemporal analysis and mapping of coastal erosion caused by open-mining areas. Environ. Forensics 9, (2-3), 271, 2008.

28. SEKER D. Z., KAYA S., ALKAN R. M., TANIK A., SAROGLU E. 3D coastal erosion analysis of Kilyos Karaburun region using multi-temporal satellite image data. Fresen. Environ. Bull. 17, (11b), 1977, 2008

29. VAN T. T., BINH T. T. Application of remote sensing for shoreline change detection in Cuu Long Estuary. VNU J. Sci. Earth Sci. 25, 217, 2009.

30. FORD M. Shoreline changes interpreted from multi-temporal aerial photographs and high resolution satellite images: Wotje Atoll, Marshall Islands. Remote Sens. Environ. 135, 130, 2013.

31. OZTURK D., BEYAZIT I., KILIC F. Spatiotemporal analysis of shoreline changes of the Kizilirmak Delta. J. Coastal Res., 2015. doi:10.2112/JCOASTRES-D-14-00159.1] [In Press].

32. ASHWORTH P. J., BEST J. L., RODEN J. E., BRISTOW C. S., KLAASSEN G. J. Morphological evolution and dynamics of a large, sand braided-bar, Jamuna River, Bangladesh. Sedimentology 47, 533, 2000.

33. TAKAGI T., OGUCHI T., MATSUMOTO J., GROSSMAN M. J., SARKER M. H., MATIN M. A. Channel braiding and stability of the Brahmaputra River, Bangladesh, since 1967: GIS and remote sensing analyses. Geomorphology 85, (3-4), 294, 2007

34. TURAN B., TURAN F., BUTUN M. D. Kizilirmak River's flood risk map and riverbed arrangement in Corum-Obruk Dam downstream. 3. National Flood Symposium, Istanbul, 29-30 April, 2013 [In Turkish].

35. YILMAZ C. Geographical analysis of erosion in the Kizilirmak Delta. TURQUA Turkey Quaternary Symposium V, Istanbul, 02-05 June 2005 [In Turkish].

36. UZUN A. Deltas in Samsun and predicted changes. In From The Past To The Future: Samsun. Yilmaz, C., Ed., Samsun Metropolitan Municipality-Department of Culture and Education Services: Samsun, pp. 541-548, 2006.

37. AYAN A. K. Use of Natural Resources in the Kizilirmak Delta, 2007. Available online: http://kizilirmakdeltasi.net/2014/dosya/rapor.pdf (Accessed 11 August 2014) [In Turkish]

38. YUKSEK O. Investigation of erosion at the west coast of Samsun. Samsun City Symposium, Samsun, 27-29 November 2008 [In Turkish]
39. OZDEMIR S. Actual Coastline Changes in the Kizilirmak Delta and Its Results. MSc Thesis, Institute of Social Sciences-Ondokuz Mayis University, Samsun, 2010.

40. ERCIYAS-YAVUZ K. An important natural area: Kizilirmak Delta. Samsun Symposium, Samsun, 13-16 October, 2011 [In Turkish].

41. ZEYBEK H. I., UZUN A., YILMAZ C., OZDEMIR S. The impacts of the shoreline changes of the Kizilirmak Delta. Samsun Symposium, Samsun, 13-16 October 2011 [In Turkish].

42. AVSIN N. Geomorphology of the Kizilirmak Valley between Sarihidir-Ciftedam (Avanos). MSc Thesis, Institute of Social Sciences-Ankara University, Ankara, 2006 [In Turkish].

43. AVSIN-GORENDAGLI N. The role of climate and tectonic in the formation of Kizilirmak river terraces, Avanos. Turk. J. Geogr. Sci. 9, (2), 221, 2011 [In Turkish].

44. TURKISH MINISTRY OF ENVIRONMENT AND FOREST. Environmental Atlas. General Directorate of Environmental Impact Assessment and PlanningDepartment of Environmental Inventory, Turkish Ministry of Environment and Forest, Ankara, 2004 [In Turkish].

45. TURKISH MINISTRY OF FORESTRY AND WATER AFFAIRS. Kirsehir Nature Tourism Master Plan (20132023). Available online:

http://bolge9.ormansu.gov.tr/9bolge/Files/dogaturizm/kirsehir il_doga_turizm_master_plan.pdf (Accessed 16 September 2014).

46. ONAL S. Flow Forecasting of the Kizilirmak River with Artificial Neural Network Method. MSc Thesis, Institute of Science and Technology-Suleyman Demirel University, Isparta, 2009 [In Turkish].

47. BAHADIR M. A statistical analysis of the flow changes of the Kizilirmak River. Turk. Stud. 6, (3), 1339, 2011 [In Turkish].

48. DOGAN U., KOCYIGIT A., WIJBRANS J. The evolutionary history of the Kizilirmak River, Cappadocia Region: An inference to the beginning of the neotectonic regimes in Central Anatolia. Turkey. 62. Geological Congress, Ankara, 13-17 April 2009 [In Turkish].

49. AKKAN E. Geomorphology of the Kizilirmak Valley Between the Junction of Delice Tributary and Cape Bafra. A.U. DTCF: Ankara, 1970 [In Turkish].

50. YENIYURT C., HEMMAMI M., CAGIRANKAYA S., KOOPMANSCHAP E. Assessment Report of Wetland Management Plan for Ramsar Areas in Turkey. Nature Association, Ankara, 2011 [In Turkish].

51. CAGIRANKAYA S. S., MERIC B. T. Turkey's Important Wetlands, RAMSAR Areas. General Directorate of Nature Conservation and National Parks-Department of Sensitive Areas, Turkish Ministry of Forestry and Water Affairs, Ankara, 2013 [In Turkish].

52. TURKISH MINISTRY OF FORESTRY AND WATER AFFAIRS. A National Watershed Management Strategy (2014-2023). http://www.resmigazete.gov.tr/eskiler/2014/07/2014070423.htm (Accessed 12 September 2014) [In Turkish].

53. TURKISH GENERAL DIRECTORATE OF STATE HYDRAULIC WORKS. Dams. http://barajlar.dsi.gov.tr (Accessed 05 August 2014) [In Turkish].

54. U.S. GEOLOGICAL SURVEY. Earth Explorer, http://earthexplorer.usgs.gov/ (Accessed January 5, 2014).

55. KRAUS N. C., ROSATI J. D. Interpretation of Shoreline Position Data for Coastal Engineering Analysis. Coastal Engineering Technical Note, CETN-II-39, U.S. Army Corps Engineer Coastal Hydraulic Laboratory, 1997. 
56. BARNARD P. L., REVELL D. L., ESHLEMAN J. L., MUSTAIN N. Carpinteria Coastal Processes Study, 20052007. Final Report, U.S. Geological Survey, Open-File Report 2007-1412, 2008.

57. BRUCE C. M., HILBERT D. W. Pre-Processing Methodology For Application to Landsat Tm/Etm+ Imagery of The Wet Tropics. Research Report, Cooperative Research Centre for Tropical Rainforest Ecology and Management, James Cook University, Australia, 2006.

58. CHANDER G., MARKHAM B. L., HELDER D. L. Summary of current radiometric calibration coefficients for Landsat MSS, TM, ETM+, and EO-1 ALI sensors. Remote Sens. Environ. 113, (5), 893, 2009.

59. GIS AG MAPS. Landsat 8 ESUN (for Atmospheric Correction), Radiance, and TOA Reflectance. http://www.gisagmaps.com/landsat-8-atco/ (Accessed 21 June 2014).

60. U.S. GEOLOGICAL SURVEY. Using the USGS Landsat 8 Product. http://landsat.usgs.gov/Landsat8_Using_Product.php (Accessed 30 July 2014).

61. CHAVEZ P. S. Image-based atmospheric corrections Revisited and improved. Photogramm. Eng. Rem. S. 62, (9), $1025,1996$.

62. SONG C., WOODCOCK C. E., SETO K. C., LENNEY M. P., MACOMBER S.A. Classification and change detection using Landsat TM data: when and how to correct atmospheric effect. Remote Sens. Environ. 75, (2), 230, 2001.

63. MANCINO G., NOLÈ A., RIPULLONE F., FERRARA A. Landsat TM imagery and NDVI differencing to detect vegetation change: assessing natural forest expansion in Basilicata, southern Italy. iForest 7, 75, 2014.

64. MCFEETERS S. K. The use of the normalized difference water index (NDWI) in the delineation of open water features. Int. J. Remote Sens. 17, (7), 1425, 1996.

65. XU H. Modification of normalised difference water index (NDWI) to enhance open water features in remotely sensed imagery. Int. J. Remote Sens. 27, (14), 3025, 2006.

66. EZIASHI A. C. An appraisal of the existing descriptive measures of river channel patterns. J. Environ. Sci. 3, (2), 253, 1999.

67. CROSATO A. Analysis and Modelling of River Meandering. IOS Press: Amsterdam, 2008.
68. SINGH R. Y. Sustainable management of headwater resources: Interface drainage analysis of a water divide. In Sustainable Management of Headwater Resources: Research from Africa and India. Jansky, L., Haigh, M. J., Prasad, H., Eds., United Nations University Press, pp. 87105, 2005.

69. BRIGGS D., SMITHSON P. Fundamentals of Physical Geography. Rowman \& Littlefield: New Jersey, 1986.

70. JAGERS H. R. A. Modelling Planform Changes of Braided Rivers. PhD Thesis, University of Twente, The Netherlands, 2003.

71. LI Z., ZHU C., GOLD C. Digital Terrain Modeling: Principles and Methodology. CRC Press: Boca Raton, 2005.

72. COOLEY S. W. GIS4Geomorphology: Channel Sinuosity. http://www.gis4geomorphology.com (Accessed 01 August 2014).

73. ETHRIDGE F. G., SCHUMM S. A. Fluvial seismic geomorphology: A view from the surface. In Seismic Geomorphology: Applications to Hydrocarbon Exploration and Production. Davies, R. J., Posamentier, H. W., Wood, L. J., Cartwright, J. A., Eds., Geological Society, Special Publication: London, pp. 205-222, 2007.

74. SUMMERFIELD M. A. Global Geomorphology. Wiley: New York, 1991.

75. SHIN Y. H., JULIEN P. Y. Changes in hydraulic geometry of the Hwang River below the Hapcheon Re-regulation Dam. Int. J. River Basin Manage. 8, (2), 139, 2000.

76. SCIENTIFIC AND TECHNOLOGICAL RESEARCH COUNCIL OF TURKEY. Havza Koruma Eylem Planlarının Hazırlanması Projesi: Kızılırmak Havzası. Sonuç Rapor, TÜBİTAK MAM, 2010 [In Turkish].

77. SERTEL E., FINDIK S., KAYA N., SEKER D. Z., SAMSUNLU A. Assessment of landscape changes in the Kizilirmak Delta, Turkey, using remotely sensed data and GIS. Environ. Eng. Sci. 25, (3), 353, 2008.

78. LU D., MORAN E., HETRICK S., LI G. Mapping impervious surface distribution with the integration of Landsat TM and QuickBird images in a complex urban-rural frontier in Brazil. In Advances of Environmental Remote Sensing to Monitor Global Changes. Chang N. B., Ed., CRC Press/Taylor and Francis, pp. 277-296, 2011. 